症例

内翻した Meckel 惒室を先進部とした成人腸重積の 1 例

\author{
聖マリアンナ医科大学第 2 外科 \\ 奥 村 権 太前田壽哉 野 崎 久充 \\ 吉 岡輝 史 丹生谷 直樹岩崎 光 彦
}

症例は 33 歳男性. 生来健康であった。

突然心漓部痛が出現し，近医受診，症状は一時軽快したが，繰り返し症状が出現する ために，精查目的のため当院内科入院となった。

腹部 CT 検查にて，回盲部近傍の回腸内に，低吸収域を伴う腫場様陰影を認め，小腸造 影，腹部超音波検查で下部回腸管内に長軸方向に長い腫湟様陰影を認めた．消化管閉塞 症状は認めなかったが疼痛を繰り返し，小腸重積を疑い開腹術施行した．開腹時所見は 回盲部より $80 \mathrm{~cm}$ 口側に小腸重積を認め，腸管内に柔らかな腫瘤を触知した。重皘を ハッチンソン手技で整復したところ, 墏膜面に引き込みを伴う陥入を認め, Meckel 䅣室 が完全に内舠し, これを先進部とした腸重皘症であった. 小腸部分切除施行し, 病理組 織学的所見では, 欯室内に異所性胃粘膜組織の迷入を認めた。

Meckel 秘室が内翻し，これを先進部とした腸重積例は，本邦では39 例の報告がある.

若干の文献的考察を加えて報告する.

索引用語：Meckel 㮩室, 成人腸重積

はじめに

Meckel 数室は胎生期の卵黄腸管の遗残と考えられ ている. 消化管先天奇形の中では比較的多いものの一 つであり, 全剖験例の 1 2\%"に認められる. 今回われ われは完全に内翻した Meckel 想室が先進部となった 成人腸重皘症を経験した.内翻もしくは喤室を先進部 とした腸重積は本邦において検索範囲内では 39 例の 報告をみるが，本症例の如く完全に内翻した䅣室を先 進部とした腸重積は稀である. 若千の文献的考察を加 えて報告する。

\section{症例}

症例：33 筬男性.

主钵：心窩部痛.

家族歴：特記すべきことはない。

既往歴：特記すべきことはない。

現病歴：生来健康であったが, 平成 6 年 6 月 23 日突 然の心窝部痛にて発症. 近医受診し保存的治療により 軽快したが，同夜再度同様の症状が出現. 原因精査の ため当院内科入紹介入院となった。

1998 年 11 月 18 日受付 1999 年 1 月 5 日採用
入院時理学的所見：体温 $36.6^{\circ} \mathrm{C}$, 体格中等度, 栄養状 㦔良好, 眼瞼結膜黄染, 筫血は認めず。腹部は平坦. 触診において心窝部より膸部にかけて軽い圧痛を認め る. 筋性防御, 反挑痛は認めず. 腫㾗も触知しなかっ た.

入院時検查所見：血液生化学的所見值，腫場マー カー値に異常所見は認めなかった.

腹部単純 $\mathbf{X}$ 線検查：腸管の拡張, 鏡面像形成などの 異常所見は認めなかった。

小腸造影検查：回腸末端部近傍に長軸方向に長い陰 影欠損を認めた．表面は比較的平滑であり体位変換に よる形状の変化は認めなかった（Fig. 1).

腹部 CT 検查：回盲部近傍の回腸内部に低吸収域を 伴う腫湟様陰影を認めた（Fig. 2).

腹部超音波検查：右側腹部腸管内に腹部 CT 同様に 腫瘤状陰影欠損を認めた（Fig. 3).

経過中, 消化管の閉塞症状は認めなかったが, 疼痛 を繰り返し次第に症状が増悪したため，小晹腫韵の疑 いにより外科転科，開腹手術を施行した。

開腹時所見：開腹時, 腹水の貯留は認めなかった。 腹腔内を検索したところ，回盲部より口側 $80 \mathrm{~cm}$ の部 


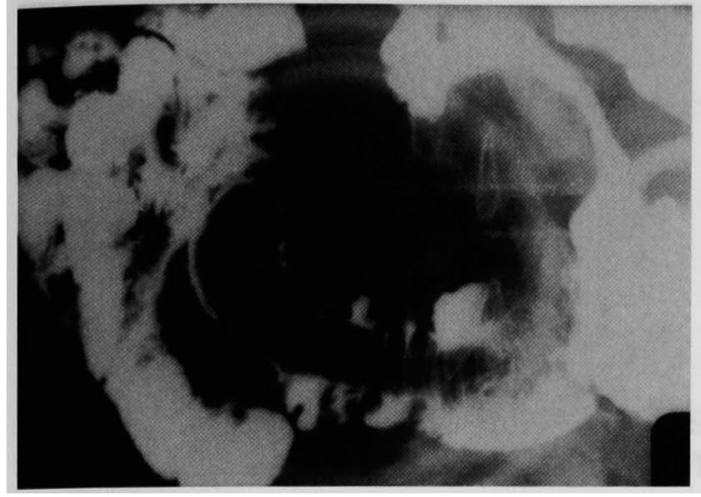

Fig. 1 小㩆造影険查: 回腸末端部近傍に長軸方向に 長い陰影欠損を認めた。

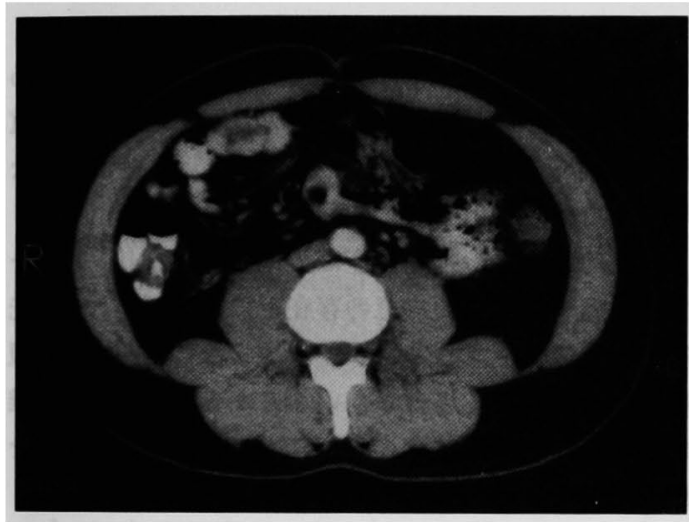

Fig. 2 做部 CT 検查：回盲部近傍の回腸内部に低吸 収域を伴う腫堭様陰影を諗めた。

位において回腸が重積を起こしており，腸管内に柔ら かな腫㿎を触知した（Fig.4）。

腸重皘をハッチンソン手技にて徒手整復した，腸管 に虚血性変化は認めなかった。腸間膜対側の槳膜面に 腸管膜の引き込みを伴う宿入を認め(Fig. 5), Meckel 䄭室が完全に内翻し，これを先進部とした腸重皘と診 断した. 内翻は整復することができず，約 $10 \mathrm{~cm} に$ たり回腸部分切除術を施行した。

切除梅本: Meckel 秘室は完全に内翻しており先端 部は壁の肥厚により $20 \times 12 \times 12 \mathrm{~mm}$ 大に腫大し一部 びらんを呈していた。

秘室の長さは約 $6 \mathrm{~cm}$ で, 腸管膜付着部对側に存在 していた (Fig.6).

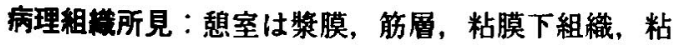
膜全層を認める真性㮩室であり，先端部に胃粘膜組織 の迷入を認めた（Fig. 7).

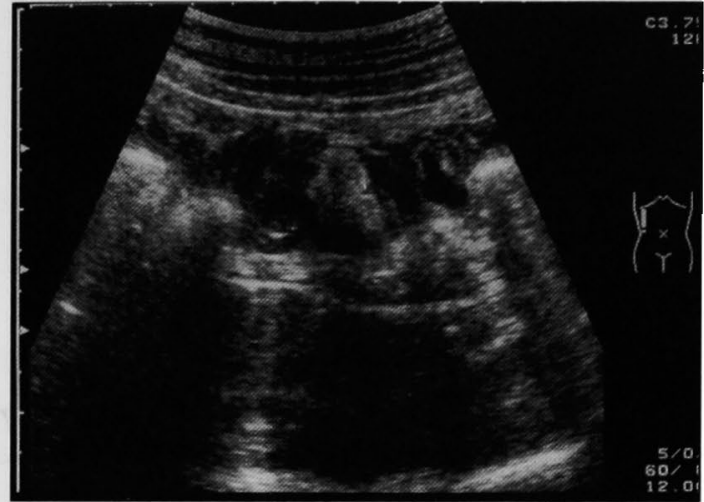

Fig. 3 肢部超音波検查：右側腹部腸管内に腹部 CT 同様に腫瘤状陰影欠損を認めた。

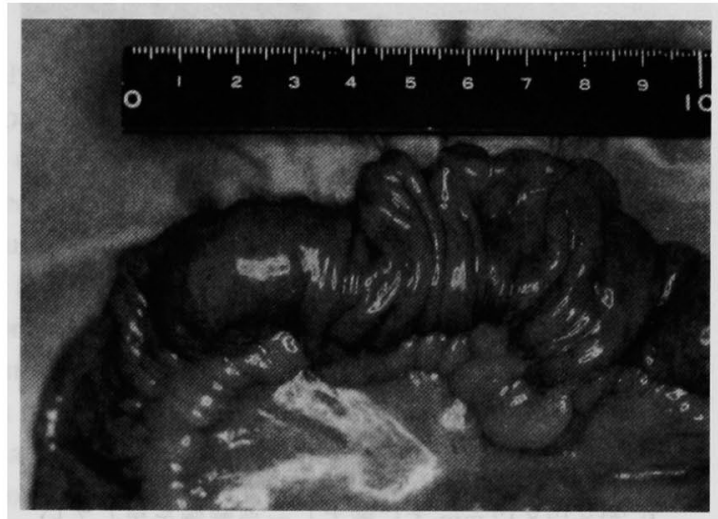

Fig. 4 回盲部より口側 $80 \mathrm{~cm}$ の部位において回腸が 重皘を起こしていた。

悪性所見は認めなかった.

術後第 11 病日に軽快退院した。

\section{考察}

Meckel 䕀室は小児に比較的多い先天性奇形であり， 胎生期の卵黄腸管の遺残と考えられている. 全剖験例 の1〜2\%に認められ，その $76.6 \%$ が開腹手術の際に 偶然に発見されている1)-3).

Meckel 䕀室は一般的に無症状に経過する場合が多 いが，臨床的に問題となるのは多彩な合併症を示すこ とであり，田中ら゙による本邦集計例によれば，腸閉塞 $40.6 \%$, 腸重皘 $13.2 \%$, 悡室炎 $15.7 \%$ ，出血 $6.8 \%$ ，穿 孔 $6.2 \%$, ヘルニア内容 $6.2 \%$ 等となっている.

Meckel 賏室の特徽として，異所性粘膜の迷入が知ら れているが(15), 病理組織としては, Ruterford $5^{61} に よ$ ると, 148 症例中胃粘膜 51 例，膆組織 10 例，結腸粘膜 2 例とあり, 本邦の田中ら"の集計によると 444 症例中 


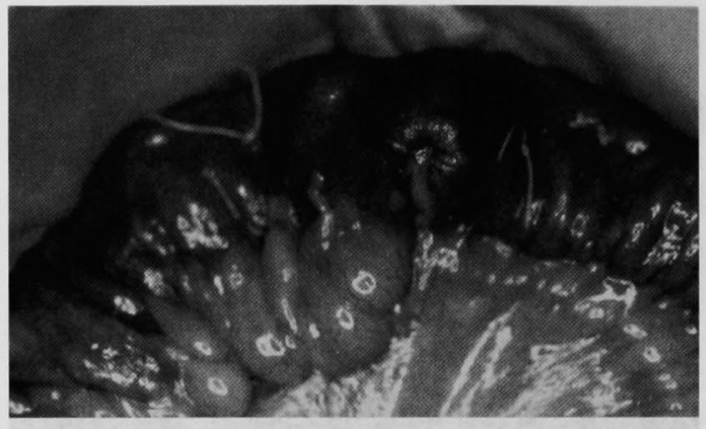

Fig. 5 腸管の墏膜面に腸管膜の引き込みを伴う陥入 を認めた

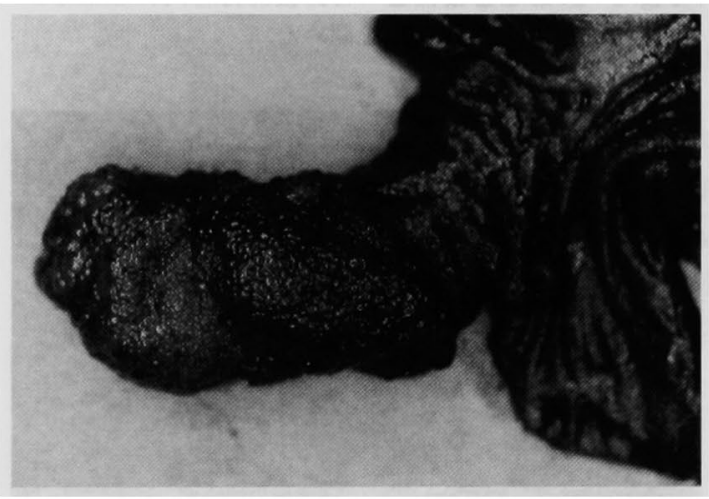

Fig. 6 切除槚本所見: Meckle 㮩室は約 $6 \mathrm{~cm}$ にわ たって完全に内翻しており，先端部は壁の肥厚によ り $20 \times 12 \times 12 \mathrm{~mm}$ 大に腫大し一部糜爛を呈してい た.

胃粘膜 22 例, 䐙組馧 13 例, 胃十二指腸粘膜 4 例等で ある。このような症例では，胃粘膜組織よりの胃酸分 泌による㮩室茎部の出血, 潰瘍が生じる可能性がある. 本症例に於て胃粘膜の迷入が認められたが，これらの 症状は認めなかった。

Meckel 想室が炎症, 肥厚等により，完全に内翻する といったことは稀である．数室が内翻する機序として は，症説や刺激による腸蠕動六進説，腸管の蝡動運 動中に腸管内圧が陰圧となり秝室が内腔に引き込まれ ることなどが推測されている7818

内翻の程度については本邦報告例には詳細な記載が されていないものが多く，本症例のように $6 \mathrm{~cm} に も$ わたって完全に内翻していた報告は検索範囲内におい ては認めない.

本症例の治療法は，一般的な成人腸重皘の治療法と 同様であり，原則的には Hutchinson 手技に準じて腸 重積の整復を試み, Meckel 鄎室などによる良性疾患が

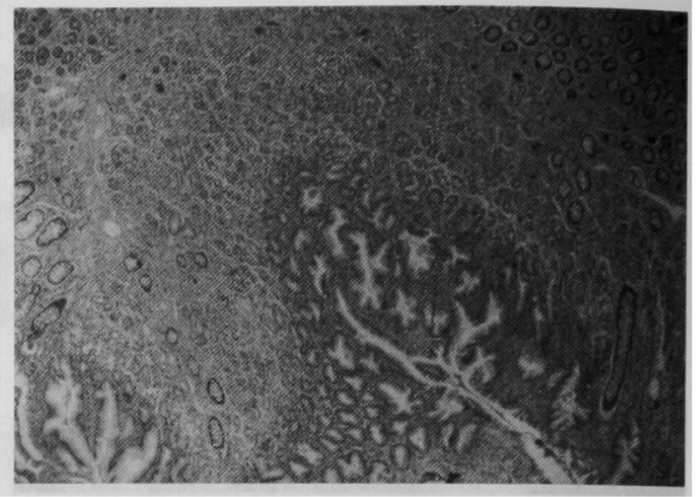

Fig. 7 病理組线所見：想室は獎膜，筋層，粘膜下組 織，粘膜全層を認める真性憩室であり，先端部に胃 粘膜組織の迷入を認めた。

原因の場合は腸管切除は最小限にとどめるべきであ

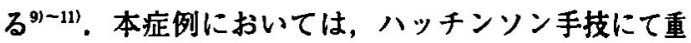
積は整復できたが, Meckel 䅣室の内翻は整復できな かったため, 約 $10 \mathrm{~cm}$ の小腸部分切除を施行した。

一般的に成人の腸重積症は小児とは異なり，ポリー プや腫瘍等の器質的疾患の存在下においてそれらを先 進部として発症することが多い．またこれらは急性腹 症として発症する場合が多いことから術前診断が困難 である. 成人腸重積症の原因で Meckel 㮩室の存在を 念頭に置くことは大切である.

\section{結語}

今回われわれは $6 \mathrm{~cm}$ の Meckel 憩室が完全に内翻 しこれは先進部とした成人腸重積症を経験したので 報告した。

本論文の要旨は第 755 回外科集談会において発表した.

\section{文嗝}

1）田中早苗, 打田荦三, 国米欣明他：Meckel 息室一 本邦 444 例の統計的観察を中心に一，外科訜療 $13: 818-826,1971$

2) Weinstein EC, Cain JC. Remain WH, et al : Meckel's diverticulum : 55 years of clinical and surgical experience. JAMA 182: 131-133, 1962

3）清成正智：卵巣出血を伴える Meckel 稳室の1例 と自験例 4 例を含めて本邦における Meckel 款室 の統計的観察. 日消病会誌 $61: 199-204,1964$

4）黑岩厚二郎, 沢田俊夫, 真下一索他：内翻した巨大 な Meckel 憩室を先進部とした腸重積症の1例. 消外 $7: 1961$ - 1964,1984

5）藤野幸夫, 村田宣夫, 井上 勇 : 内翻した Meckel 彭室を先進部とした成人腸重皘症の 1 例. 日消外 会誌 $24: 3027-3031,1991$ 
6) Rutherford RB, Akers DR : Meckel's diverticulum. A view of 148 pediatric patients with special reference to the pattern of bleeding and to mesodiverticular vascular bands. Surgery $59: 618-$ 626. 1966

7) Edwards $\mathrm{HC}$ : Diverticula and Diverticulitis of the intestine. William Wood Medical Book, Williams and Wilkins Co, Baltimore, 1939. p 5-50

8）平井伸司, 村松豪晁, 丸山高司：内翻した Meckel
秝室が先進部となった腸重積症の1例。臨外 47:271-274, 1992

9）小田高司, 蜂須賀喜多男,山口晃弘他：成人腸重皘 症の検討. 臨外 $44: 111-115,1989$

10）奥村脩一，長田 裕, 黑田大介：成人腸重積症の診 断と治療について。外科 $51: 1465-1469,1989$

11）花村典子，木田英也, 赤坂義和：内翻 Meckel 㕷室 による成人腸重皘症の 1 例. 日消外会誌 56 ： 1632-1636, 1995

\title{
ADULT INTUSSUSCEPTION CAUSED BY COMPLETE INTROVERSION OF MECKEL'S DIVERTICULUM-REPORT OF A CASE-
}

\author{
Gonta OKUMURA, Toshiya MAEDA, Hisamitsu NOZAKI, Terufumi YOSHIOKA, \\ Naoki NIBUTANI and Mitsuhiko IW ASAKI \\ Second Department of Surgery. St. Marianna University School of Medicine
}

A 33-year-old man who was born healthy had suddenly had an epigastric pain and consulted another hospital. Because of recurrent bouts of the pain after a temporal remission, the patient was admitted to the department of internal medicine in our hospital for close examination. Abdominal CT revealed a tumorous shadow with low-density area in the ileum near the ileocecal region. Fluoroscopic study of the small intestine and abdominal ultrasonography visualized a long tumorous lesion longitudinally in the lower portion of ileum. No symptoms of intestinal obstruction were seen but the pain recurred frequently. So a laparotomy was performed with a suspicion of small bowel tumor. During operation, an intussusception of the small intestine 80 $\mathrm{cm}$ oral side from the ileocecal region was demonstrated and a soft tumor was palpated in the intestine. When the intussusception was relieved by means of Hutchinson manuever, an invagination with withdrawal on the serosa was revealed that was a complete introversion of a Meckel's diverticulum which caused the intussusception. A partial excision of the small intestine was performed. Histopathological study revealed abberation of ectopic gastric mucous tissue in the diverticulum.

There have been 39 cases of intussusception caused by introversion of Meckel's diverticulum in Japan. Some bibliographical comments are also presented here. 